\title{
A semi-empirical SCF-M 0 study on the base-pairing properties of 8-oxopurines: significance for mutagenicity
}

\author{
D ivi Venkateswarlu, ${ }^{a}$ R . H . D uncan $L$ yngdoh $^{b}$ and $M$ anju Bansal ${ }^{a}$ \\ a M olecular Biophysics U nit, I ndian Institute of Science, Bangalore 560 012, India \\ ${ }^{b}$ D epartment of Chemistry, N orth-E astern H ill U niversity, Shillong 793 003, India
}

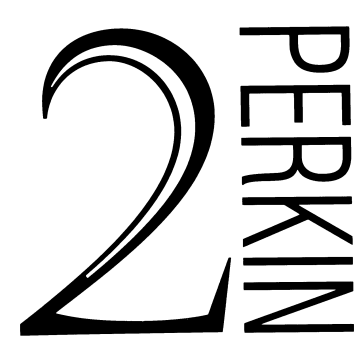

\begin{abstract}
$C^{8}$-0 xidised purines like 7-hydro-8-oxoguanine (80 G) and 7-hydro-8-oxoadenine (80A) are known as products of oxidative D N A damage. Semiempirical molecular orbital calculations at the PM 3 SC F-M 0 level are used to investigate the base-pairing properties of these bases in an attempt to understand their mutagenic properties. A detailed analysis of the base-pairing properties of these bases leads to an identification of the most probable pairing schemes involved in mutagenic base-mispairing. It is suggested that both bases are capable of inducing transversional as well as transitional mutations via basemispairing. The results presented are largely in consonance with available experimental reports.
\end{abstract}

\section{Introduction}

The reactive oxygen species generated by in vivo oxidative metabolism or by exogenous agents such as ionising radiation or chemical oxidants have been widely implicated for $C^{8}$ modification of D N A purine bases. ${ }^{1-3}$ There has been wide interest in the properties of these oxidised bases owing to the appreciable incidence of cellular damage by oxidative agents ${ }^{4}$ (ca. $10^{4}$ oxidative hits per day). It is widely believed that $C^{8}$-oxidation of purines could play a key role in the aging process as well as in degenerative diseases such as cancer ${ }^{5-9} \mathrm{~A}$ mong the various oxidation products of DNA bases, 7-hydro-8-oxoguanine (8OG) and 7-hydro-8-oxoadenine (80A) have received wide attention owing to their mutation inducing properties. ${ }^{10-12}$

\section{Tautomers of 8-oxopurines}

These modified bases as monomers can adopt several tautomeric structures. Fig. 1 shows the predominant and the most stable minor tautomeric forms of $80 \mathrm{~A}$ and $80 \mathrm{G}$. U nder physiological conditions, the 6,8-dioxo species (80G in Fig. 1) is reported to predominate ${ }^{13}$ over the others. However, NMR spectral evidence by Kouchakdjian et al. indicates the presence of ca. $15 \%$ of the minor tautomers in the case of $80 \mathrm{G} .{ }^{14} \mathrm{The}$ significance of minor tautomers, particularly the enol forms, in mutagenic base-mispairing therefore cannot be ruled out. $G$ asphase ab initio studies at ST 0-3G level also indicated that the 6,8-dioxo form predominates in $80 \mathrm{G}$ with the minor 6-enol-8keto tautomer (80G* in Fig. 1) being energetically very close to the major tautomer. ${ }^{15}$ While not much is known about the tautomeric preferences of $80 \mathrm{~A},{ }^{15} \mathrm{~N} \mathrm{~N} \mathrm{M} \mathrm{R} \mathrm{studies} \mathrm{on} 80 \mathrm{~A}$ suggest that while the 8-keto form ( $80 \mathrm{~A}$ in $\mathrm{Fig.} \mathrm{1)}$ predominates under physiological conditions, the minor 8-enol tautomer $\left(80 \mathrm{~A} *\right.$ in $\mathrm{Fig} .1$ ) may also exist at high $\mathrm{pK}_{\mathrm{a}}$ values. $^{16}$

\section{Template properties of 8-oxopurines}

The D N A template properties of $80 \mathrm{dG}$ indicate in vivo ${ }^{17-19}$ and in vitro ${ }^{20,21}$ mutagenic properties. Translesional synthesis can proceed past $80 \mathrm{dG}$ in primed template reactions catalysed by DNA polymerase, in which case $d A$ and/or $d C$ is inserted opposite the lesion. The $80 \mathrm{dG}: \mathrm{dA}$ pair is readily extended by DNA polymerase and does not appear to be subject to the editing function of this enzyme.21

H owever, the base-mispairing and mutagenic specificity of $80 \mathrm{dG}$ is not clearly known. The in vivo study by $\mathrm{C}$ heng et al. of complementary bacteriophage plaque colour assays, using 80 pGTP and DNA polymerase, illustrated the mutagenic properties of $80 \mathrm{G}$ as a template causing $\mathrm{G} \longrightarrow \mathrm{T}$ substitutions, while misincorporation of $80 \mathrm{G}$ as substrate caused<smiles>Nc1nc2[nH]c(=O)[nH]c2c(=O)[nH]1</smiles><smiles>Nc1nc(O)c2[nH]c(=O)[nH]c2n1</smiles><smiles>Nc1nc2c(c(=O)[nH]1)NC(=O)N1C(CO)OCC21</smiles>

8OdG (syn)<smiles>Nc1ncnc2[nH]c(=O)[nH]c12</smiles>

$8 \mathrm{OA}$<smiles>Nc1ncnc2c1[nH]c(=O)n2C1CC(O)C(CO)O1</smiles>

8OdA (syn)<smiles></smiles>

8OdG (anti)<smiles>Nc1ncnc2[nH]c(O)nc12</smiles>

$8 \mathrm{OA}^{*}$<smiles>Nc1ncnc2c1[nH]c(=O)n2C1CC(O)C(CO)O1</smiles>

8OdA (anti)

Fig. 1 Structural formulae for various 8-oxobases and nucleosides studied

$\mathrm{A} \longrightarrow \mathrm{C}$ substitutions. Both are believed to be caused by $80 \mathrm{G}:$ A $^{\text {mispairs. }}{ }^{19}$

While these studies have shown the possibility of only $G$ to $T$ type transversional mutations, in vivo studies on the hot spots of $\mathrm{c}-\mathrm{H}$ a-ras genes raised the possibility of other types of mutations as well. ${ }^{22,23}$ While $G$ to $T$ type mutations were induced in 
the first positions of codons 12 and 61 , the D N A lesion at the second position of codon 12 induced a $G$ to $A$ transition in addition to a $G$ to $T$ transversion, thus demonstrating the possibility of transitional mutations too from $80 \mathrm{G} .^{22} \mathrm{~T}$ he question then arises as to which tautomeric form of $80 \mathrm{G}$ is responsible for these $G$ to $A$ transitions. It may be argued that $80 \mathrm{G}$ can itself mispair with thymine in its native form leading to such mutations, while the possible involvement of a minor eno tautomer of $80 \mathrm{G}$ in stabilising such mispairs cannot be ruled out. Here, a detailed structural study on the base-mispairing specificities and underlying pairing energies of these oxidised bases would throw much light on the understanding of 8oxopurine induced mutagenesis.

In contrast to $80 \mathrm{G}, 8$-oxoadenine (80A) is not particularly mutagenic, being at least an order of magnitude less mutagenic than 8-oxoguanine ${ }^{24}$ Evans and co-workers have shown that $80 \mathrm{G}$ and $80 \mathrm{~A}$ have strong structural similarities. ${ }^{13,16,25}$ Both these lesions predominate at physiological $\mathrm{pH}$ in the native 8keto form and appear to adopt the syn conformation about the glycosyl bond. X-R ay studies on a dodecanucleotide duplex have shown that the most likely alternative base-pair $\mathrm{G}: 80 \mathrm{~A}$ is asymmetric, and is similar to a purine-pyrimidine mismatch, ${ }^{26}$ whence it may be argued that this could be an easy target for repair enzymes. On the other hand, the reported crystal structure containing $80 \mathrm{G}$ has shown that it forms a stable pair with cytosine and is found to exist in the normal anti form. ${ }^{27} \mathrm{How}$ ever, there has so far been no other report of the basemispairing properties of $80 \mathrm{~A}$ and model studies on possible mispairs could help to clear the picture.

The present work, utilising a semi-empirical molecular orbital model, is aimed at understanding mutation-inducing properties of 8-oxopurines, as well as seeking out the structural rationale behind the mutagenic potential of various base-pairing motifs. This could yield insight into the types of mutation and structural forms of the lesions involved in the free-radical induced mutagenesis.

\section{Theoretical methodology}

The structural and energetic characteristics of various basepair motifs adopted by $80 \mathrm{G}$ and $80 \mathrm{~A}$ are studied here using the PM 3 SCF -M O method. ${ }^{28}$ This method has been used widely to study the hydrogen-bonded complexes of both nucleic acid bases and small polar molecules by various workers and shown to be superior over other semi-empirical SC F -M O methods. ${ }^{29-32}$ Recently, it has been substantiated to be the only semi-empirical methodology (using the NDDO scheme) with any ability to properly reproduce experimentally observed hydrogen bonding between nucleotide base pairs. ${ }^{33}$

The thermodynamics of base-pair formations was gauged from the enthalpy of base-pairing $E_{p}$, obtained from the heats of formation of the pair and of the individual bases. $N$ ote was taken of the number and lengths $R_{H \mathbf{X}}$ or $R_{\mathbf{X Y}}$ of the hydrogen bonds formed. This could allow for the possibility of correlating the magnitude of the pairing energy $E_{p}$ with the number of hydrogen bonds observed, and also with their length. All the bases here are methylated at the $\mathrm{N}^{\mathbf{1}}$ (in case of pyrimidines) or $\mathrm{N}^{9}$ position (in the case of purines) in order to mimic the sugar moiety in D N A.

The internal configuration of a base-pair was gauged by various markers, viz. the distance $R_{N N}$ between the two glycosidic nitrogen atoms, the distance $R_{c c}$ between the carbon atoms of the two methyl groups attached to $\mathrm{N}^{1}$ (for pyrimidine bases) or $\mathrm{N}^{9}$ (for purine bases) ring atoms, the buckle and propeller twist between the two base planes, the angles, $\theta_{1}$ and $\theta_{2}$, between the two glycosidic and $\mathrm{C}^{\prime}-\mathrm{Cl}^{\prime}$ vectors. Comparison of the values of these configurational markers for a particular base-pair with those for the standard Watson-Crick base-pairs could lead to a proper evaluation of the degree with which the given base-pair resembled or departed from the standard

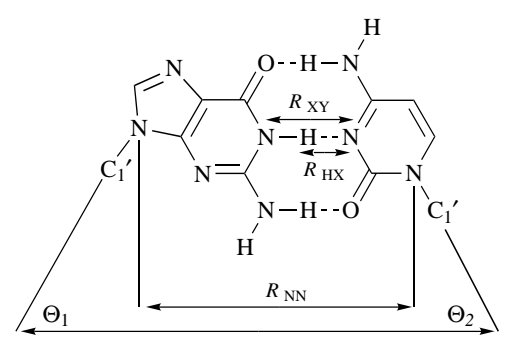

Fig. 2 Schematic representation of various configurational markers monitored in the present study

double-helical configuration. The schematic representation of various configurational markers observed in the present study are shown in Fig. 2.

All the structures were fully optimised using the eigenvector following (EF) method, ${ }^{34}$ with the PR ECISE option in effect, as incorporated into the M OPAC 6.1 package, ${ }^{35}$ and were characterised as true minima, with all $\mathrm{H}$ essian eigenvalues being positive. Various configurational parameters obtained in the present work were calculated using a modified version of NU PAR M ${ }^{36}$ program.

\section{Results and discussion}

\section{Base-pairing properties of 8-oxoguanine}

In principle, $80 \mathrm{G}$ can pair with other bases to form four different types of motifs, which may lead to various types of mutagenic or non-mutagenic events: (1) $80 \mathrm{G}$ can pair with cytosine in normal Watson-Crick fashion leading to a non-mutagenic pairing situation; (2) $80 \mathrm{G}$ can pair with thymine either in native or tautomeric form leading to a $\mathrm{G} \longrightarrow \mathrm{A}$ type transitional mutagenic event; (3) $80 \mathrm{G}$ can form a base pair with adenine in either syn or anti fashion, i.e. using either its $\mathrm{H}$ oogsteen face or Watson-Crick respectively, leading to $G \longrightarrow T$ type transversional mutagenic event; and (4) $80 \mathrm{G}$ can also pair with guanine, leading to $\mathrm{G} \longrightarrow \mathrm{C}$ type substitutions. This wide range of pairing possibilities offers an interesting opportunity to study the stability of various pairs in the context of the in vivo and in vitro mutagenicity reported for $80 \mathrm{G}$, particularly so since the precise structural details of mutation induction by $80 \mathrm{G}$ are not well understood. A schematic representation of some of the mispairs studied in the present work are shown in Fig. 3.

Table 1 presents the calculated data for various base-pairing schemes adopted by $80 \mathrm{G}$ at the PM 3 SCF -M O level. Theresults obtained in the present work compare qualitatively with the previous conformational studies on D N A duplexes containing $80 \mathrm{G}$ and using JU M NA classical potential energy algorithm. ${ }^{37}$ The sequences examined were $d\left(A_{5} X A_{5}\right)-d\left(T_{5} Y T_{5}\right)$ and $d\left(G_{5} X G_{5}\right)$ $d\left(C_{5} Y C_{5}\right)$ with $X$ or $Y$ being $80 \mathrm{G}$. Within the limited pairing combinations studied, they observed the following order of stability in both duplexes, when one of the bases is 80 G, eqn. (1).

$$
80 G_{a}: C_{a} \approx G_{a}: C_{a}>80 G_{s}: G_{a} \approx 80 G_{a}: T_{a} \approx 80 G_{s}: A_{a} \text { (1) }
$$

Thus, the classical potential function is only able to differentiate between the Watson-Crick pairs and the mismatches but not among the various mismatches. The present calculations using a more accurate quantum mechanical method leads to a clear differentiation in the pairing energies among hydrogen bonded base-pairing motifs in the various possible mismatches. The following order of pairing energies for various base-pairing combinations between $80 \mathrm{G}$ and other nucleic acid bases is obtained, eqn. (2).

$$
\begin{aligned}
80 G_{a}: C_{a}>G_{a}: C_{a}>80 G_{a}: T_{a}>G_{a}: T_{a} \approx \\
80 G_{a}: A_{a}>80 G_{s}: 80 G_{a}>G_{a}: A_{a}>80 G_{a}: T_{a}> \\
80 G_{s}: G_{a}>G_{a}: A_{s}>G_{a}: T_{a} \approx 80 G_{s}: A_{s}>80 G_{a}: A_{s}> \\
\quad 80 G_{s}: A_{a}>80 G_{s}: T_{a}>80 G_{a}: G_{s} \approx G_{a}: G_{s}
\end{aligned}
$$


<smiles></smiles>

$8 \mathrm{OG}_{\mathrm{a}}: \mathrm{C}_{\mathrm{a}}(-13.08)$<smiles></smiles>

$8 \mathrm{OG}_{\mathrm{a}}: \mathrm{T}_{\mathrm{a}}(-6.78)$

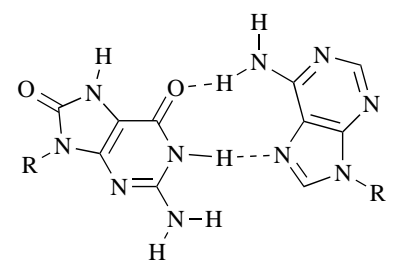

$8 \mathrm{OG}_{\mathrm{a}}: \mathrm{A}_{\mathrm{s}}(-5.49)$<smiles>[R]N1C=Nc2c(nc(N)n([TlH])c2=O)N1[IH2]</smiles>

$80 G_{\mathrm{s}}: \mathrm{G}_{\mathrm{a}}(-6.51)$

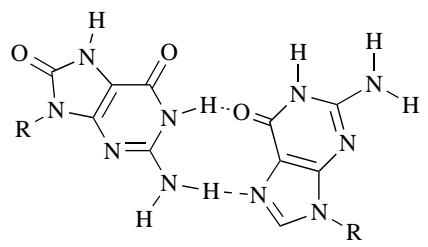

$80 G_{\mathrm{a}}: \mathrm{G}_{\mathrm{s}}(-3.12)$

Fig. 3 Schematic representation of some plausible base-mispairing schemes that can be adopted by 8-oxoguanine, pairing energies $\left(E_{p}\right)$ $\mathrm{kcal} \mathrm{mol}^{-1}$ ) are given in parentheses

It is immediately obvious from the data that $80 \mathrm{G}$ shows a clear preference to pair with cytosine in the normal WatsonCrick fashion, the pairing energy of this pair being $1.2 \mathrm{kcal}$ $\mathrm{mol}^{-1}(1 \mathrm{cal}=4.184 \mathrm{~J})$ more favourable than the normal $\mathrm{G}: \mathrm{C}$ pair. The only reported crystal structure containing $80 \mathrm{G}$ has shown that it forms a stable pair with cytosine and is in the normal anti form. ${ }^{27}$ It may bealso noted that the $80 \mathrm{G}: \mathrm{C}$ pair is very similar to the standard $\mathrm{G}: \mathrm{C}$ Watson-Crick configuration, as is evident from all the configurational markers listed in Table 1.

The 6-enol-8-keto tautomer of $80 \mathrm{G}$ (80 G* in Fig. 1) has been shown by ab initio study ${ }^{15}$ to be energetically very close to the 6,8-diketo species and may exist in significant population in vivo. Table 1 reveals that $80 \mathrm{G} *$ can pair with thymine in the normal anti form with a good pairing energy $\left(-8.3 \mathrm{kcal} \mathrm{mol}^{-1}\right)$, and this pairing scheme may be held responsible for $G \longrightarrow A$ type transitional mutations. $80 \mathrm{G}$ in its normal diketo tautomeric form can compete in pairing with thymine leading to the same kind of transitional mutation though the resultant basepair is relatively less stable $\left(-6.8 \mathrm{kcal} \mathrm{mol}^{-1}\right)$. The other pairing scheme between $80 \mathrm{G}$ in syn configuration and thymine in anti form may be a rather unlikely event, as reflected by the unfavourably short glycosidic distances and low pairing energy (3.7 $\mathrm{kcal} \mathrm{mol}^{-1}$ lower than for the 80G*:T pair). In the absence of structural data on this type of mutagenic lesion, the base-mispairing motifs $80 G *_{a}: T_{a}$ and $80 G_{a}: T_{a}$, may both be proposed as competing possibilities leading to $a \mathrm{G} \longrightarrow$ A type transitional mutation.

Pairing of $80 \mathrm{G}$ with adenine would be responsible for a $\mathrm{G} \longrightarrow \mathrm{T}$ type transversion. Table 1 presents four possibilities where $80 \mathrm{G}$ in either syn or anti conformation pairs with adenine. Out of these, $80 \mathrm{G}$ (anti) pairing with adenine (anti) is energetically more favourable than the other three possible motifs. Even though, the configurational features of this pair suggest that it may not be easily accommodated into a DNA doublehelix because of a much wider separation between glycosidic nitrogens ( $\mathrm{N}^{9}-\mathrm{N}^{9}$ distance of ca. $11 \AA$ ), a similar base-mispair of the type $G_{a}: A_{a}$ has in fact been observed in N M R and crystallographic studies of oligonucleotides. ${ }^{38,39}$ The next possible base-pair $80 \mathrm{G}_{\mathrm{s}}: \mathrm{A}_{\mathrm{s}}$ has a pairing energy ca. $1.8 \mathrm{kcal} \mathrm{mol}^{-1}$ less than $80 G_{a}: A_{a}$. D espite being a very symmetric base-pairing configuration, this structure may be ruled out in a duplex owing to the very short glycosidic bond distance. The next possible base mispair $80 \mathrm{G}_{\mathrm{s}}: \mathrm{A}_{\mathrm{a}}$ is ca. $2.2 \mathrm{kcal} \mathrm{mol}^{-1}$ less favourable than $80 G_{a}: A_{a}$. Interestingly, this pair is conformationally very stable, with minimal perturbation to the duplex stability as reflected by various configurational parameters. The base-pair $80 G_{s}: A_{a}$ is also energetically and conformationally very close to $80 G_{a}: A_{s}$. However, despite the close structural similarity between these base-pairs, only the former base-pair is generally believed to be responsible for the experimentally observed $\mathrm{G} \longrightarrow \mathrm{T}$ transversional mutations. Taking a cue from the close structural similarity between these two base-pairs, it may be argued that there exists a strong possibility of competition between these two pairs leading to purine-purine mismatches.

DNA duplexes containing $80 \mathrm{G}_{\mathrm{s}}: \mathrm{A}_{\mathrm{a}}$ base-mispair have been shown to cause minimal distortion to the global conformation by various structural and theoretical studies. ${ }^{14,36}$ These types of purine-purine mismatches among normal DNA bases have also been identified and characterised by various $X$-ray and N M R studies. ${ }^{38-41,43-46}$ The observed base-pairing preference of $80 \mathrm{G}$ (syn) for adenine(anti), despite low pairing energy, may be attributed to sequence-specific stabilisation of this mismatch basepair, as has been observed for normal $\mathrm{G}: \mathrm{A}$ base mispairs in oligonucleotide duplexes. In summary, it may be concluded that the three mismatches $80 G_{a}: A_{a}, 80 G_{s}: A_{a}$ and $80 G_{a}: A_{s}$ may all exist in DNA duplexes, depending on the sequence context of the duplex.

Lastly, 80 G can pair with guanine leading to a $G \longrightarrow C$ type transversion, in three different ways. Though only of the oretical interest, the $80 G_{s}: 80 G_{a}$ pair is energetically favoured over the other two possibilities, viz. the $80 G_{s}: G_{a}$ and $80 G_{a}: G_{s}$ pairs. Excluding the possible occurrence of this mispair in vivo, $80 \mathrm{G}$ may be expected to pair in the other two possible ways. The data predict that the $80 \mathrm{G}_{\mathrm{s}}: \mathrm{G}_{\mathrm{a}}$ pair is $3.4 \mathrm{kcal} \mathrm{mol}^{-1}$ more favourable than the $80 \mathrm{G}_{\mathrm{a}}: \mathrm{G}_{\mathrm{s}}$ pair. Since the pairing energy of the $80 G_{s}: G_{a}$ mispair is slightly more favourable than that of the mutagenic lesion $80 \mathrm{G}_{\mathrm{s}}: \mathrm{A}_{\mathrm{a}}$ (by ca. $1.2 \mathrm{kcal} \mathrm{mol}^{-1}$ ) and in view of its close structural homology with the normal WatsonCrick configuration, it may be expected that this mispair may compete with $\mathrm{G}: \mathrm{A}$ type mismatches.

\section{Base-pairing properties of 8-oxoadenine}

$U$ nlike the case of $80 \mathrm{G}$, the mutagenic role of $80 \mathrm{~A}$ is much less studied. Comparative studies on the genetic effects of $80 \mathrm{G}$ and $80 \mathrm{~A}$ have indicated that $80 \mathrm{~A}$ is at least an order of magnitude less mutagenic than $80 \mathrm{G}$ in $\mathrm{E}$. coli cells with normal DNA repair capabilities. ${ }^{24} 80 \mathrm{~A}$ can adopt mispairing schemes leading 
Table 1 PM 3 data for various base-pairing motifs between $80 \mathrm{G}$ and nucleic acid bases ( $\mathrm{N}^{1} / \mathrm{N}^{9}$ positions of all bases are methylated)

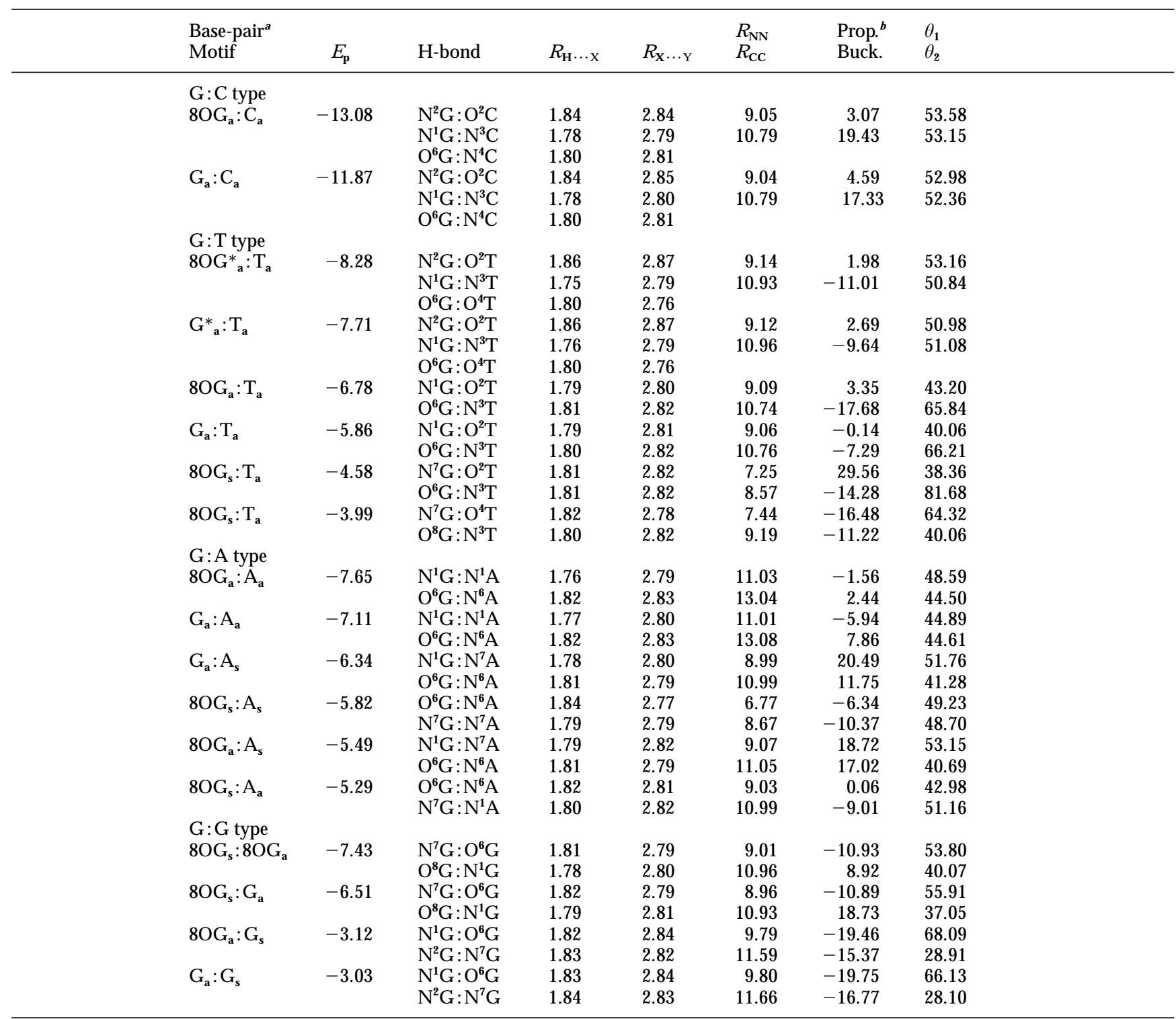

${ }^{a}$ *represents minor tautomeric form $80 \mathrm{G} *$ (see $\mathrm{Fig} .1$ ); all pairing energies $\left(\mathrm{E}_{\mathrm{p}}\right)$ are in $\mathrm{kcal} \mathrm{mol}{ }^{-1}$, distances $(\AA)$ angles $\left({ }^{\circ}\right) .{ }^{\mathrm{b}}$ Propeller and buckle parameters between the two base planes are calculated using the N U PA R M ${ }^{37}$ program.

to either transitional or transversional mutagenic events. We put forward three types of mispairing schemes, within the normal Watson-Crick configuration, possible in the case of $80 \mathrm{~A}$ : (1) $80 \mathrm{~A}$ pairs in either native or tautomeric form with thymine, leading to a non-mutagenic base-pairing situation; (2) $80 \mathrm{~A}$ pairs with guanine, leading to an $A \longrightarrow C$ transversion; and (3) $80 \mathrm{~A}$ pairs with cytosine, leading to an $A \longrightarrow G$ transition. $\mathrm{Fig.} 4$ illustrates the structural forms of various mispairs that can be adopted by $80 \mathrm{~A}$.

The data in Table 2 presents the pairing possibilities of $80 \mathrm{~A}$ with all other nucleic acid bases in either the syn or anti conformation. Of these, the 6-amino-8-enol form of 8-oxoadenine (80A* in $\mathrm{Fig} .1$ ) in the syn conformation pairs very favourably with thymine, with the formation of three hydrogen-bonds, and is ca. $5 \mathrm{kcal} \mathrm{mol}^{-1}$ more stable than the normal A:T pair. This, however, is not a mutagenic event. Significant participation of this base-mispair would be critically dependent on the $\mathrm{pH}$ of the environment since ionisation of $N^{7}$ has been observed only at a $\mathrm{pH}$ above 8.7 and the base-pair is also geometrically very difficult to accommodate in a duplex. Thus, under physiological conditions, it may be ruled out as a competing base mispair. However, $80 \mathrm{~A}$ itself can pair with thymine in both the anti and syn conformation. These basepairs, $80 \mathrm{~A}_{\mathrm{a}}: \mathrm{T}_{\mathrm{a}}$ and $80 \mathrm{~A}_{\mathrm{s}}: \mathrm{T}_{\mathrm{a}}$ have pairing energies very similar to an $A_{a}: T_{a}$ pair, but only the former has a near normal base-pair configuration. Thus, it may be expected that the pair $80 \mathrm{~A}_{\mathrm{a}}: \mathrm{T}_{\mathrm{a}}$ may compete with normal base-pairs, leading, of course, to a non-mutagenic situation.

A s shown in Table 2, 80A can pair with guanine in at least three ways leading to $A \longrightarrow C$ type transversions. The pair involving $80 \mathrm{~A}(\mathrm{syn})$ with guanine(anti) is an interesting one. This base-pair is $2.6 \mathrm{kcal} \mathrm{mol}^{-1}$ more stable than the normal $A: T$ pair, and leads to a conformationally very stable basepairing situation. ${ }^{26} \mathrm{D}$ espite its stability when compared with the widely studied $80 G_{s}: A_{a}$ mispair (which leads to transversional mutations both in vivo and in vitro), the $80 \mathrm{~A}_{s}: G_{a}$ pair has not been attributed much mutagenic significance in experimental studies. The $80 A_{s}: G_{a}$ pair has been shown to be an order of magnitude less mutagenic than the $80 \mathrm{G}_{s}: \mathrm{A}_{\mathrm{a}}$ pair. ${ }^{24} \mathrm{H}$ owever, recent in vivo studies on $\mathrm{C}-\mathrm{Ha}$ a-ras gene $\mathrm{NIH} 3 \mathrm{~T} 3$ cells by $\mathrm{K}$ amiya et al. indicate that $80 \mathrm{~A}$ is capable of inducing both $\mathrm{A} \longrightarrow \mathrm{G}$ type transitional and $\mathrm{A} \longrightarrow \mathrm{C}$ transversional mutations. ${ }^{22}$ This observation is quite noteworthy and throws further light on the structural elements through which D N A repair proteins, such as $M$ utT, recognise base-pair mismatches. It has been argued that the pattern of hydrogen-bond donorsacceptors in the major groove regions of these mispairs might be a differentiating factor for repair enzymes to recognise the mispairing. ${ }^{27}$ Our results support this hypothesis since the pos- 
Table 2 PM 3 data for various base-pairing motifs between $80 \mathrm{~A}$ and nucleic acid bases ( $\mathrm{N}^{1} / \mathrm{N}^{9}$ positions of all bases are methylated)

\begin{tabular}{|c|c|c|c|c|c|c|c|}
\hline $\begin{array}{l}\text { Base-pairb } \\
\text { M otif }\end{array}$ & $E_{p}$ & $\mathrm{H}$-bond & $\mathrm{R}_{\mathrm{H} \cdots \mathrm{x}}$ & $R_{X} \cdots Y$ & $\begin{array}{l}R_{\mathrm{NN}} \\
\mathrm{R}_{\mathrm{CC}}\end{array}$ & $\begin{array}{l}\text { Prop. } \\
\text { Buck. }\end{array}$ & $\begin{array}{l}\theta_{1} \\
\theta_{2}\end{array}$ \\
\hline $\begin{array}{l}\text { A }: T \text { type } \\
80 A *_{s}: T_{a}\end{array}$ & -10.70 & $\begin{array}{l}O^{8} \mathrm{~A}: \mathrm{O}^{2} \mathrm{~T} \\
N^{7} \mathrm{~A}: \mathrm{N}^{3} \mathrm{~T} \\
\mathrm{~N}^{6} \mathrm{~A}: \mathrm{O}^{4} \mathrm{~T}\end{array}$ & $\begin{array}{l}1.79 \\
1.73 \\
1.86\end{array}$ & $\begin{array}{l}2.76 \\
2.76 \\
2.84\end{array}$ & $\begin{array}{l}6.83 \\
8.50\end{array}$ & $\begin{array}{r}-2.80 \\
-11.77\end{array}$ & $\begin{array}{l}49.20 \\
60.60\end{array}$ \\
\hline$A_{a}: T_{a}$ & -5.56 & $N^{1} A: N^{3} T$ & 1.78 & 2.82 & 9.14 & -4.00 & 51.96 \\
\hline & & $\mathrm{N}^{6} \mathrm{~A}: \mathrm{O}^{4} \mathrm{~T}$ & 1.82 & 2.83 & 10.99 & -0.93 & 49.73 \\
\hline $80 A_{a}: T_{a}$ & -5.17 & $N^{1} A: N^{3} T$ & 1.79 & 2.83 & 10.93 & 9.18 & 55.12 \\
\hline $80 A_{s}: T_{a}$ & -4.92 & $\begin{array}{l}N^{6} \mathrm{~A}: \mathrm{O}^{4} \mathrm{~T} \\
O^{8} \mathrm{~A}: \mathrm{N}^{3} \mathrm{~T} \\
\mathrm{~N}^{7} \mathrm{~A} A\end{array}$ & $\begin{array}{l}1.82 \\
1.80\end{array}$ & $\begin{array}{l}2.83 \\
2.82\end{array}$ & $\begin{array}{l}9.18 \\
7.42\end{array}$ & $\begin{array}{r}-10.31 \\
-6.10\end{array}$ & $\begin{array}{l}51.34 \\
66.08\end{array}$ \\
\hline A :G type & & $N^{7} A: 0^{4} T$ & 1.81 & 2.79 & 9.12 & 25.63 & 39.12 \\
\hline $80 A_{s}: G_{a}$ & -8.14 & $\begin{array}{l}N^{7} A: O^{6} G \\
O^{8} A: N^{1} G\end{array}$ & $\begin{array}{l}1.79 \\
1.79\end{array}$ & $\begin{array}{l}2.79 \\
2.82\end{array}$ & $\begin{array}{r}8.94 \\
11.03\end{array}$ & $\begin{array}{r}7.90 \\
-20.82\end{array}$ & $\begin{array}{l}50.00 \\
37.62\end{array}$ \\
\hline $80 A_{a}: G_{a}$ & -6.08 & $N^{1} A: N^{1} G$ & 1.78 & 2.81 & 11.02 & $\begin{array}{r}6.54 \\
-1240\end{array}$ & $\begin{array}{l}47.79 \\
44.90\end{array}$ \\
\hline $80 A *_{s}: G_{a}$ & -2.42 & $\begin{array}{l}O^{8} A: N^{2} G \\
N^{7} A: N^{1} G \\
N^{6} A: O^{6} G\end{array}$ & $\begin{array}{l}1.02 \\
1.87 \\
1.81 \\
1.80\end{array}$ & $\begin{array}{l}2.84 \\
2.84 \\
2.78\end{array}$ & $\begin{array}{r}13.04 \\
9.09 \\
11.14\end{array}$ & $\begin{array}{r}-12.40 \\
3.98 \\
-1.93\end{array}$ & $\begin{array}{l}44.90 \\
40.25 \\
50.42\end{array}$ \\
\hline $\begin{array}{l}\text { A :C type } \\
80 A_{s}: C_{a}\end{array}$ & -3.54 & $\begin{array}{l}N^{7} \mathrm{~A}: \mathrm{O}^{2} \mathrm{~T} \\
\mathrm{~N}^{6} \mathrm{~A}: \mathrm{N}^{3} \mathrm{C}\end{array}$ & $\begin{array}{l}1.81 \\
1.93\end{array}$ & $\begin{array}{l}2.81 \\
2.88\end{array}$ & $\begin{array}{l}7.26 \\
8.70\end{array}$ & $\begin{array}{r}-26.78 \\
2.93\end{array}$ & $\begin{array}{l}30.79 \\
81.18\end{array}$ \\
\hline
\end{tabular}

a See the footnotes of Table 1 for units. ${ }^{\text {b } A l l ~ b a s e s * ~ r e p r e s e n t ~ m i n o r ~ t a u t o m e r i c ~ f o r m ~} 80 \mathrm{~A} *$ (see Fig. 1).<smiles></smiles>

$8 \mathrm{OA}_{\mathrm{a}}: \mathrm{T}_{\mathrm{a}}(-5.17)$<smiles></smiles>

$80 A_{\mathrm{s}}: \mathrm{T}_{\mathrm{a}}(-4.92)$

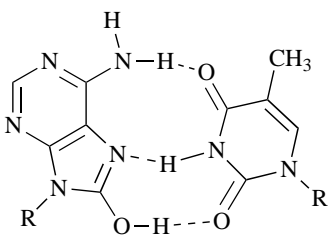

$80{ }^{*}: \mathrm{T}_{\mathrm{a}}(-10.70)$

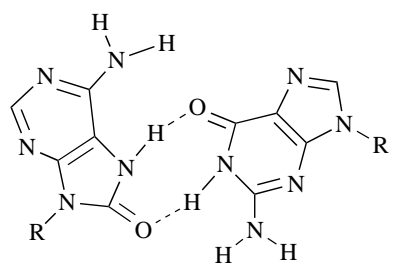

$8 \mathrm{OA}_{\mathrm{s}}: \mathrm{G}_{\mathrm{a}}(-8.14)$

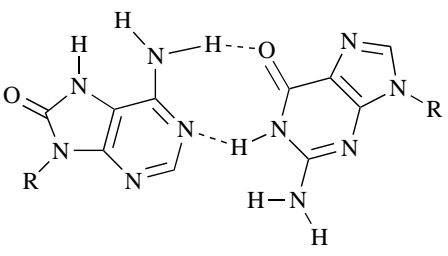

$80 A_{a}: G_{a}(-6.08)$<smiles></smiles>

$8 \mathrm{OA}_{\mathrm{s}}: \mathrm{C}_{\mathrm{a}}(-3.54)$

Fig. 4 Various plausible base-mispairing schemes that can be adopted by 8-oxoadenine, pairing energies $\left(E_{p}\right.$ in $\left.\mathrm{kcal} \mathrm{mol}^{-1}\right)$ are indicated in parentheses

sible base-mispairs adopted by both $80 \mathrm{~A}$ and $80 \mathrm{G}$ are conformationally very similar, causing little perturbation to the DN A double-helix and leading to similar base-mispairing situations from structural considerations. A nother interesting pair that $80 \mathrm{~A}$ can adopt is with guanine, both being in the normal anti conformation. Such mispairs between normal adenine and guanine were observed in various structural studies as discussed before $^{38,39} \mathrm{~N}$ ote that this pair is more stable than the normal $A_{a}: T_{a}$ pair (by ca. $0.5 \mathrm{kcal} \mathrm{mol}^{-1}$ ) and less stable than $80 A_{s}: G_{a}$. It is interesting to note that despite being of the normal Watson-C rick type, this pair is ca. $2 \mathrm{kcal} \mathrm{mol}^{-1}$ less stable than

the $\mathrm{H}$ oogsteen type pair $80 \mathrm{~A}_{\mathrm{s}}: \mathrm{G}_{\mathrm{a}}$. N onetheless, being a symmetric Watson-Crick type structure, there is a fair possibility that this pair may compete with $80 \mathrm{~A}_{\mathrm{s}}: \mathrm{G}_{\mathrm{a}}$, leading to an $A \longrightarrow C$ type transversional mutation, if not recognised by re pair enzymes such as M utT. The third possible mispair between $80 \mathrm{~A} *$ (syn) and $\mathrm{G}$ (anti) has very weak binding as indicated by its very low pairing energy and as discussed above such a mispair, of course, depends critically on the ionisation of $80 \mathrm{~A}$.

The other interesting base-mispairing situation that $80 \mathrm{~A}$ can adopt is by pairing with cytosine. The analogous base-mispair between adenine and cytosine is not possible under normal physiological conditions, though under high acidic conditions, protonated adenine can mispair with cytosine ${ }^{47}$ Despite unfavourable configurational parameters (extremely short C $1^{\prime}-$ C 1 ' distance), this mispair is the only plausible structural motif, that can be attributed for $A \longrightarrow G$ type transitional mutations under physiological conditions which have been reported recently. ${ }^{22}$

\section{Conclusions}

The detailed studies on the base-pairing properties of 8oxoguanine and 8-oxoadenine at PM 3 SCF-M O level indicate that both adducts can indeed lead to base-misincorporations during replication. In the case of 8-oxoguanine, the oxoadduct in anti form shows a preference to pair with cytosine(anti), a pairing which is energetically more stable than all other pairing combinations. The competing mispairs $80 \mathrm{G} *_{\mathrm{a}}: \mathrm{T}_{\mathrm{a}}$ and $80 G_{a}: T_{a}$ may be held responsible for $G \longrightarrow A$ type transitional mutations, while $80 G_{a}: A_{s}$ and $80 G_{s}: A_{a}$ may mutually compete with both leading to $G \longrightarrow T$ type transversional mutagenic events. Similarly, $80 \mathrm{~A}_{\mathrm{s}}: \mathrm{T}_{\mathrm{a}}$ and $80 \mathrm{~A}_{\mathrm{a}}: \mathrm{T}_{\mathrm{a}}$ might compete, both being non-mutagenic base-pairing schemes for 8oxoadenine. While $80 A_{s}: G_{a}$ and $80 A_{a}: G_{a}$ might be held responsible for $A \longrightarrow C$ type transversional mutations. Though it is structurally rather difficult to accommodate in a duplex, the $80 \mathrm{~A}_{\mathrm{s}}: \mathrm{C}_{\mathrm{a}}$ mispair may be the only possible motif to which an $A \longrightarrow G$ type transitional mutagenic event can be attributed under normal physiological conditions.

Thus, the present study though giving only approximate numbers for the relative energies for isolated base-pairs clearly indicates the large base-mispairing potential of both 8-oxoguanine and 8-oxoadenine. This can lead to several different thermodynamically facile transversional and transitional mutations involving these bases. 


\section{Acknowledgements}

D. V. is the recipient of a research associateship from the Department of Biotechnology, India.

\section{R eferences}

1 J. F. Ward, Prog. N ucleic A cid R es. M ol. Biol., 1988, 35, 95

2 M. G. Simic, D. S. Bergtold and L. R. K aram, M utat. Res., 1989, 214, 3.

3 D. C. M alins and R. Haimanot, Biochem. Biophy. Res. Commun. 1990, 173, 614.

4 E. M. Park, M. K. Shigenaga, P. D egan, T. S. Korn, J. W. K itzler, C. M. Wehr, P. Kolachana and B. N. A mes, Proc. N atl. A cad. Sci. USA, 1992, 89, 3375.

5 B. N. A mes. Free Rad. Res. Commun., 1989, 7, 121.

6 C. E. Cross, B. H alliwell, E. T. Borish, W. A. Pryor, B. N. A mes, R . I. Saul, J. M. M cC ord and D. H arman, A nn. Int. M ed., 1987, 107, 526. 7 R. A. Floyd, Carcinogenesis, 1990, 11, 1447.

8 B. H alliwell and J. M. C. Gutteridge, Free Radicals in Biology and M edicine, Clarendon, Oxford, 2nd edn., 1989.

9 L. H. Breimer, Br. J. Cancer, 1988, 57, 6.

10 H. K asai and S. N ishimura, N ucleic A cids R es., 1984, 12, 2137.

11 F. Le Page, A. M argot, A. P. G rollman, A. Sarasin and A. Gentil, Carcinogenesis, 1995, 16, 2779.

$12 \mathrm{H}$. Kamiya, H. M iura, N. M urata-Kamiya, H. Ishikawa, T. Sakaguchi, H. Inoue, T. Sasaki, C. M asutani, F. H anoaka and S. N ishimura, N ucleic A cids R es., 1995, 23, 2893.

13 S. J. Culp, B. P. Cho, F. F. K adlubar and F. E. Evans, Chem. Res. Toxicol., 1989, 2, 416.

14 M. Kouchakdjian, V. Bodepudi, S. Shibutani, M. Eisenberg, F. Johnson, A. P. G rollman and D. J. Patel, Biochemistry, 1991, 30, 1403.

15 M. A ida and S. N ishimura, M utat. Res., 1987, 192, 83.

16 B. P. Cho and F. E. Evans, N ucleic A cids Res., 1991, 19, 1041.

17 M. L. Wood, M. Dizdaroglu, E. Gajewski and J. M. Essigmann, Biochemistry, 1990, 29, 7024.

18 M. M oriya, C. Ou, V. Bodepudi, F. Johnson, M. Takeshita and A. P. G rollman, M utat. Res., 1991, 254, 281.

19 K . C. Cheng, D. S. Cahill, H. K asai, S. N ishimura and L. A, . L oeb, J. Biol. Chem., 1992, 267, 166.

20 Y. Kuchino, F. M ori, H. K asai, H. Inoue, S. I wai, K. M iura, E. Ohtsuka and S. N ishimura, N ature, 1987, 327, 77.

21 S. Shibutani, M. Takeshita and A. P. Grollman, N ature, 1991, 349, 431.

22 H. K amiya, N. M urata-K amiya, S. K oizume, H. Inoue, S. N ishimura and $\mathrm{E}$. Ohtsuka, Carcinogenesis, 1995, 16, 883.

23 S. Koizume, H. K amiya, H. Inoue and E. Ohtsuka, N ucleosides N ucleotides, 1994, 13, 1517.

24 M. L. Wood, A. Esteve, M. L. M orningstar, G. M. K uziemko and J. M . Essigmann, N ucleic A cids R es., 1992, 20, 6023.
25 B. P. Cho, S. J. Culp, F. F. K adlubar and F. E. Evans, Chem. Res. Tox., 1990, 3, 445.

26 G. A. L eonard, A. Guy, T. Brown, R. Teoule and W. N. Hunter, Biochemistry, 1992, 31, 8415.

27 L. A. Lipscombe, M. E. Peek, M. L. M orningstar, S. M. Verghis, E. M. M iller, A. R ich, J. M. Essigmann and L. D. Williams, Proc. $\mathrm{N}$ atl. A cad. Sci. U SA, 1995, 92, 719.

28 J. J. P. Stewart, J. Comput. C hem., 1989, 10, 221.

29 A. R. Leach and P. A. Kollman, J. A m. Chem. Soc., 1992, 114, 3675.

30 I. Juranic, H. S. R zepa and M. Y i, J. Chem. Soc., Perkin Trans. 2, 1990, 877.

31 D. Venkateswarlu and R. H. D. Lyngdoh, J. Chem. Soc., Perkin Trans. 2, 1995, 839.

32 M. W. Jurema and G. C. Shields, J. Comp. Chem., 1993, 14, 89

33 T. N. Lively, M. W. Jurema and G. C. Shields, Int. J. Quant. Chem., 1994, 21, 95.

34 J. Simons, P. Jorgensen, H. Taylor and J. Ozment, J. Phys. Chem., $1983,87,2745$.

35 J. J. P. Stewart, QCPE 455, available from Quantum Chemistry Program Exchange, Indiana U niversity, Bloomington, IN, U SA.

36 D. Bhattacharya and M. Bansal, J. Biomol. Struct. Dyn., 1989, 6, 10.

37 V. I. Poltev, S. L. Smirnov, O. V. Issarafutdinova and R. L avery, I. Biomol. Struct. Dyn., 1993, 11, 293.

38 L. -S. K an, S. Chandrasegaran, S. M. Pulford and P. S. M iller, Proc. $\mathrm{N}$ atl. A cad. Sci. U SA, 1983, 80, 4263.

39 G. G. Prive, U. Heinemann, S. Chandrasegaran, L.-S. K an, M. L. Kopka and R. E. D ickerson, Science, 1987, 238, 498.

40 T. Brown, W. N. H unter, G. K neale and O. K ennard, P roc. N atl. A cad. Sci. USA, 1986, 83, 2402.

41 X. G ao and D. J. Patel, J. A m. Chem. Soc., 1988, 110, 5176

42 K. E. M cAuley-H echt, G. A. L eonard, N. J. G ibson, J. B. Thomson, W. P. Watson, W. N. H unter and T. Brown, Biochemistry, 1994, 33, 10266.

43 A. N. Lane, T. C. Jenkins, D. J. S. Brown and T. Brown, Biochem. J., 1991, 279, 269.

44 T. Brown, G. A. Leonard, E. D. Booth and J. Chambers, J. M ol. Biol., 1989, 207, 455.

45 G. A. L eonard, E. D. Booth and T. Brown, N ucleic A cids R es., 1990, $18,5617$.

46 G. D. Webster, M. R. Sanderson, J. V. Skelly, S. N eidle, P. F. Swann, B. F. Li and I. J. Tickle, P roc. N atl. A cad. Sci. U SA, 1990, 87, 6693.

47 W. N. H unter, T. Brown and O. Kennard, N ucleic A cids Res., 1987, 15,6589 .
Paper 6/03927H

Received 5th J une 1996 A ccepted 18th O ctober 1996 